\title{
The Use of Derivatives to Hedge Embedded Options: The Case of Pension Institutions in Denmark
}

\author{
Jeppe Ladekarl, Regitze Ladekarl, Erik Brink Andersen and Dimitri Vittas* \\ The World Bank
}

\begin{abstract}
The main purpose of this paper is to examine the growing use of derivatives by Danish pension institutions as a risk management tool to hedge embedded options on their balance sheets. Throughout the 1980s and 1990s it was a widespread practice for Danish pension institutions to guarantee a minimum interest rate on new pension policies. With the new millennium global interest rates declined steeply and equity markets came crashing down. Suddenly the guarantees on pension contracts were in the money. The policies already written could not be changed, leaving liabilities and assets mismatched, profits in the red, and capital reserves drained. Out of necessity, and in some cases virtue, Danish pension institutions turned in scale to derivatives, allowing for a more active approach to hedging, asset and liability management, and even profit generation. Through the use of derivatives, pension institutions have avoided the need to renegotiate their guaranteed contracts with policy holders. They have succeeded as an industry in transforming their pay-off curves and have emerged with better matched asset/liability positions and lower exposure to interest rate risk. But the expanded use of derivatives also raises some risk management and regulatory issues, such as operational and counterparty risks as well as effective internal control systems and regulatory oversight.
\end{abstract}

JEL Classification Code: G11, G15, G22, G23, G28, G31

Keywords: Defined Benefit, Defined Contribution, Risk Management, Swaps, Hedging, Dynamic Capital Projection, Asset and Liability Management, Liability Driven Investment

\section{World Bank Policy Research Working Paper 4159, March 2007}

The Policy Research Working Paper Series disseminates the findings of work in progress to encourage the exchange of ideas about development issues. An objective of the series is to get the findings out quickly, even if the presentations are less than fully polished. The papers carry the names of the authors and should be cited accordingly. The findings, interpretations, and conclusions expressed in this paper are entirely those of the authors. They do not necessarily represent the view of the World Bank, its Executive Directors, or the countries they represent. Policy Research Working Papers are available online at http://econ.worldbank.org.

\footnotetext{
* Jeppe Ladekarl (jladekarl@worldbank.org) is from the World Bank’s Treasury Department , Regitze Ladekarl and Erik Brink Andersen are independent consultants, and Dimitri Vittas is a consultant formerly with the World Bank. The authors are grateful to Messrs. Glaessner, Jonasson, Lybek, and numerous regulators, pension managers and investment bankers in London and Copenhagen who shared their insights and experiences and provided comments and suggestions.
} 


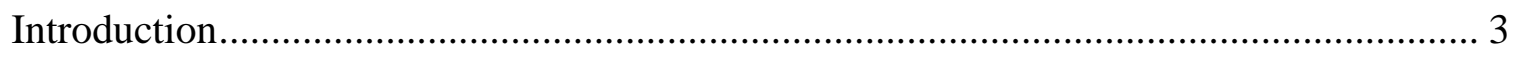

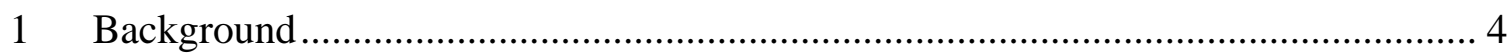

1.1 The Danish Pension System .............................................................................. 4

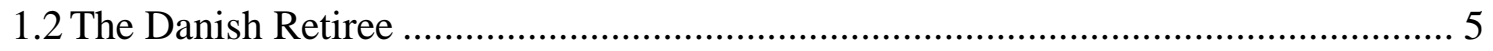

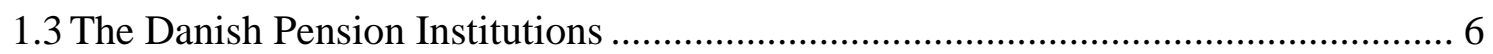

2 Income Statements and Balance Sheet Composition................................................ 7

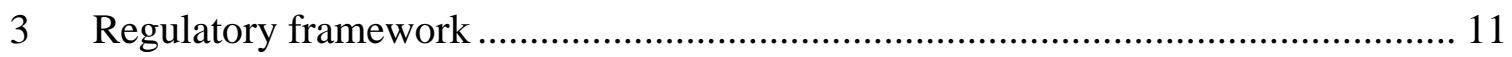

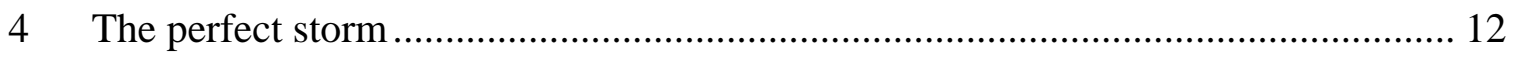

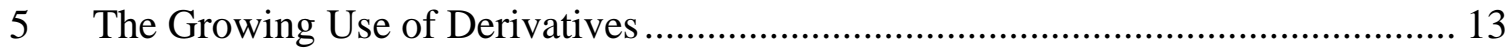

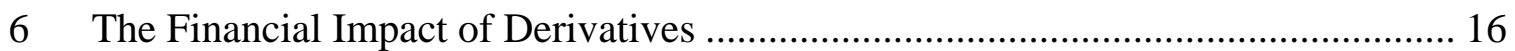

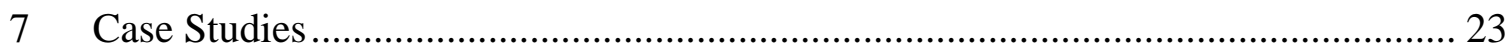

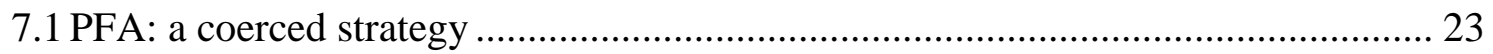

7.2 ATP: a proactive strategy ............................................................................... 24

7.3 Magistrenes Pensionskasse (MP): a passive strategy ……....................................... 26

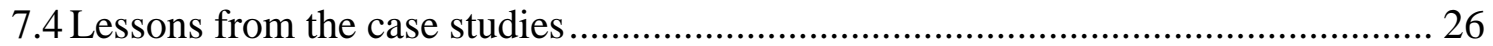

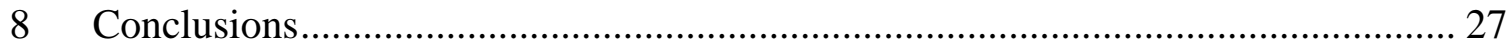

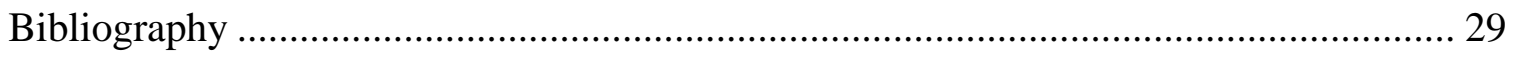




\section{INTRODUCTION}

Throughout the 1980s and 1990s it was a widespread practice for Danish life insurance companies and pension funds (henceforth pension institutions) to guarantee a minimum interest rate on new pension policies. This practice was also followed in several other countries in continental Europe. The guaranteed rates were low by comparison to the high nominal rates that prevailed at the time; the guarantees were thus seen as a mere technicality and were granted to policyholders without charge. At the same time, pension institutions invested heavily in callable mortgage bonds that constitute a large component of the Danish financial system. Callable bonds allow borrowers to refinance their mortgages at par when interest rates fall and thus expose pension institutions to asymmetric interest rate risk.

With the new millennium global interest rates declined steeply and equity markets came crashing down. The pension institutions were caught between several rocks and hard places. Suddenly both the guarantees on their pension contracts and the prepayment options on their mortgage assets were in the money. The policies already written could not be changed, leaving liabilities and assets mismatched, profits in the red, and capital reserves drained. However, it was not until accounting rules were changed to require mark-to-market valuation of the balance sheet and supervisory requirements began focusing on the ability of pension institutions to withstand stress scenarios that most of them started addressing the situation in earnest.

Out of necessity, and in some cases virtue, derivatives have been an essential part of the solution, allowing for a more active approach to hedging, asset and liability management, and even profit generation. Through the use of derivatives, pension institutions have avoided the need to renegotiate their guaranteed contracts with policy holders. They have succeeded as an industry to transform their pay-off curves and emerged with better matched asset/liability positions and lower exposure to interest rate risk.

The successful use of derivatives to hedge embedded options has positive implications for the offer of financial products that mitigate the exposure of policy holders to financial risk. But the expanded use of derivatives also raises some risk management and regulatory issues, such as operational and counterparty risks as well as effective internal control systems and regulatory oversight.

The main purpose of this paper is to examine the growing use of derivatives by Danish pension institutions as a risk management tool to hedge embedded options on their balance sheets. To set these issues in context, this discussion is preceded by a brief description of the Danish pension system and its regulatory framework. The main sections of the paper focus on the balance sheet composition of pension institutions, the "perfect storm" that hit pension institutions in all advanced countries in the early 2000s, and the financial impact of the use of derivatives. Three small case studies are used to illustrate different responses to the problems arising from the unfavorable market conditions. The concluding section draws together the policy lessons from recent Danish experience. 


\section{BACKGROUND}

To give a better understanding of how derivatives have been used to hedge embedded options in the Danish case, this section provides a brief description of the Danish pension system, its main institutions, and its regulatory framework. ${ }^{1}$

\subsection{THE DANISH PENSION SYSTEM}

The Danish pension system consists of three pillars. The first pillar - the social pension - ensures a minimum pension for everyone regardless of employment status and history. It is a pay-as-you-go system and is publicly funded from general tax revenues. All Danish citizens are eligible for this pension from the age of 65 . There is a basic social pension that roughly corresponds to 20 percent of average earnings and a means-tested supplement that may double the social pension, effectively ensuring that all pensioners receive at least 40 percent of average earnings. Additional support is provided through housing benefits and free access to the universal healthcare system.

The second pillar - occupational pensions - is an integral part of the Danish collective bargaining system and is funded by contributions from employers and employees. Typically, the employer contributes two thirds and the employee one third. Participation for workers covered by different collective labor agreements is mandatory. The contribution rate varies with the specific plan. It has steadily grown over the past decade and the average contribution rate now exceeds 10 percent of wages. In $200277 \%$ of the labor force contributed more than $7 \%$ of their gross salary to pensions; up from $4 \%$ in $1998 .{ }^{2}$ Most pension plans are based on defined-contribution schemes. Retirement benefits depend on contributions and investment returns. But pension plans also offer death and disability benefits. Payouts can take various forms: lump sums, phased withdrawals, or life annuities ${ }^{3}$, depending on the specific plan.

The third pillar - personal pensions - covers additional private saving. In many ways these personal pension plans resemble the occupational pension plans, but participation is entirely voluntary and the plans are funded solely by the participants, although favored by partial tax exemption. Like pillar 2 schemes, payouts can be as lump sum payments, phased withdrawals, or life annuities.

In addition to the three pillars the Danish pension system also includes a number of statutory supplementary pension schemes. The supplementary schemes could be construed as being part of pillar 1 as they cover a large part of the population - in some cases much more than the work force - but their institutional setup and funding compares better to pillar 2 plans.

\footnotetext{
${ }^{1}$ A more comprehensive description and analysis is provided in Andersen and Skjodt (2006) and Van Dam and Brink Andersen (2006).

${ }^{2}$ Danmarks Nationalbank (2006).

${ }^{3}$ One of the differences between phased withdrawals and annuities is that annuities are strictly personal. In case of death the remaining savings will not be paid out, whereas phased withdrawals will be paid out to next of kin. This has become a disputed point in some divorce cases as annuities are seen as a way of preventing ex-spouses from getting any part of the savings.
} 
The Labor Market Supplementary Pension Fund (ATP) is by far the largest of the supplementary pension schemes. It was set up in 1964 to ensure all wage earners a savings-based supplement to the social pension. Later its coverage was extended to unemployed workers and other recipients of social transfers. Today most citizens between the age of 16 and 65 contribute to the ATP and are eligible for supplementary benefits. ATP benefits take the form of life annuities unless the saved amount is too small in which case a lump sum withdrawal is permitted. ATP pensions can be paid out from the $65^{\text {th }}$ birthday or deferred until the $70^{\text {th }}$ birthday.

The Special Pension Savings scheme (SP) is the second largest supplementary scheme. It was introduced in 1998 as a fiscal policy tool meant to slow down consumer spending and increase pension saving. As economic winds changed contributions to the scheme were suspended in 2003, but while it was in effect, it was mandatory for all wage earners to contribute one percent of their gross salary. SP benefits depend on the size of contributions and investment returns. They take the form of phased withdrawals over a ten-year period with payouts starting on retirement. But like ATP, small accumulated amounts are paid out as lump-sums.

The third supplementary pension scheme is the Employees’ Capital Pension Fund (LD). LD was established in 1978. Its objective was more an economic policy measure than a pension savings program. In the late 1970s most wages were adjusted upwards several times per year to account for rising price levels. The Danish government wanted to contain this very inflationary practice and decided in 1976 that only one annual wage adjustment to prices would be allowed and the rest would be frozen and held in LD personal accounts until retirement. From 1977 to 1979 two adjustments - amounting to DKK 7.7 billion - were frozen and later transferred into 2.5 million individual accounts in LD. Payout is in the form of a lump sum at any point after the retiree's $60^{\text {th }}$ birthday.

\subsection{THE DANISH RETIREE}

The Danish pension system is built around the intention of ensuring an adequate pension for everyone. Established in 1892, the social pension is one of the first European public pension schemes and for many decades it has been the main income source for Danish senior citizens. Only since the 1980s have occupational and personal pension plans come to play a significant role in promoting financial security in retirement. However, this shift is seen as a permanent trend, as the table below illustrates.

Table 1: Average individual income sources and distribution in retirement, 1997 and 2045

\begin{tabular}{l|c|c|c|c}
\hline Income sources in 1997 prices (DKK 1,000) & $\begin{array}{c}1997 \\
\text { DKK }\end{array}$ & $\begin{array}{c}1997 \\
\text { Percent }\end{array}$ & $\begin{array}{c}2045 \\
\text { DKK }\end{array}$ & $\begin{array}{c}2045 \\
\text { Percent }\end{array}$ \\
\hline National pension and public benefits & 73 & 45 & 127 & 33 \\
Labor market pensions and individual savings & 36 & 23 & 136 & 36 \\
Supplementary pensions & 5 & 3 & 53 & 14 \\
Interest and Dividends on Savings & 47 & 29 & 63 & 17 \\
\hline Total gross income & 161 & 100 & 379 & 100 \\
Taxes & 40 & 25 & 103 & 27 \\
\hline Net income & 121 & 75 & 276 & 73 \\
\hline Source: The
\end{tabular}

Source: The Danish Government, 2000 
With the increasing importance of personal pension plans, replacement rates have become a more common measurement of pension coverage. Even though the categorization does not strictly adhere to the pillars of the pension system, figure 1 shows that net replacement rates will surpass 90 percent over the next 15 years and it will all be due to occupational and personal savings as the relative income from the social pension will diminish. The increasing replacement rates and growing savings are partly driven by a change in the general view of what retirement should be. People are retiring earlier and living longer, which in itself raises the financial requirements. In addition, the prospect of healthier and more active years makes for a demand for not only security, but financial prosperity in retirement, which can only be attained by personal savings.

Figure 1: Expected development in replacement ratios, 2000 - 2050

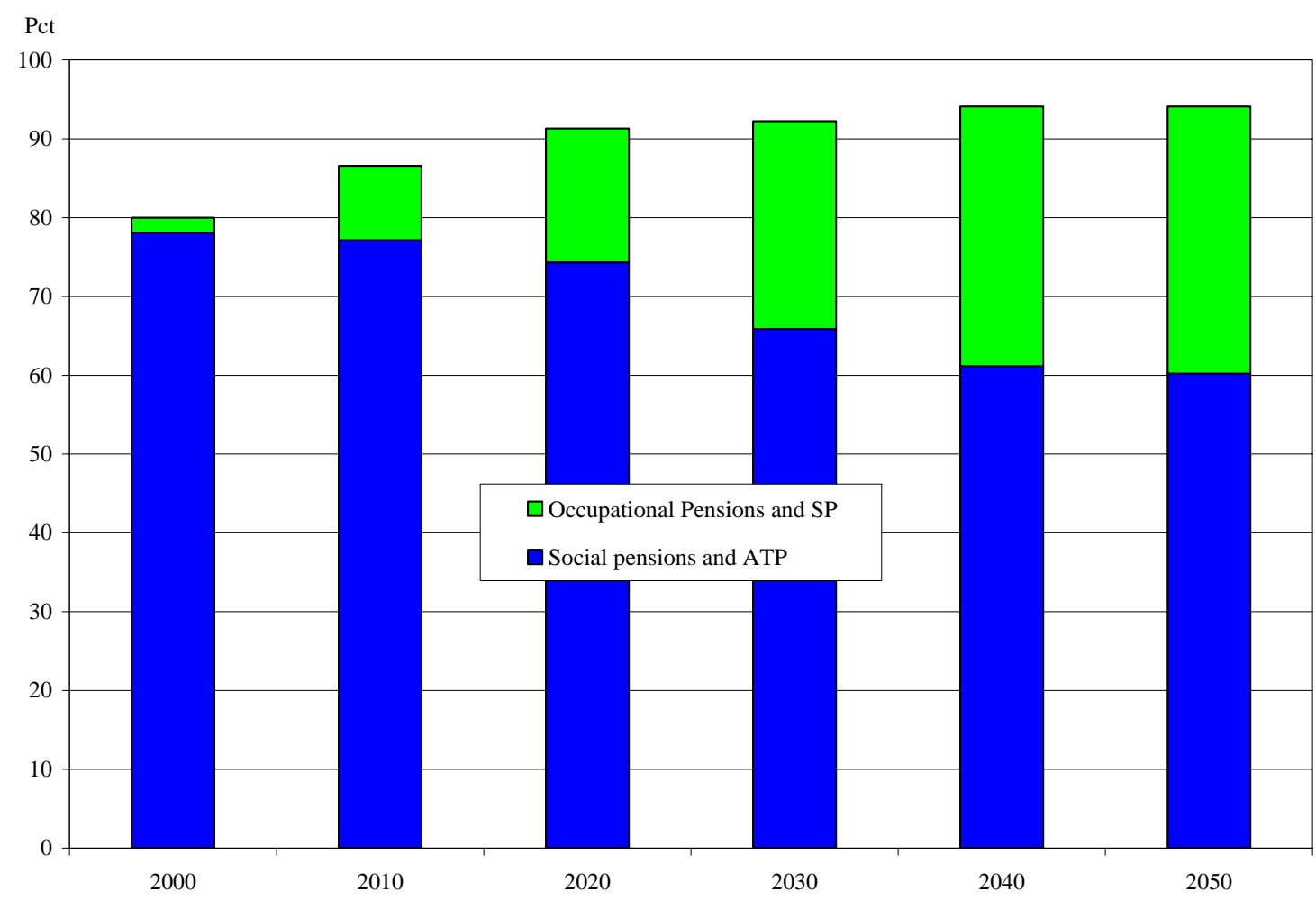

Source: The Ministry of Economic and Business Affairs

\subsection{THE DANISH PENSION INSTITUTIONS}

Life insurance companies are the most important group of pension institutions with over $40 \%$ of total assets (Table 2). They are established either as shareholderowned joint-stock companies or as policyholder-owned mutual companies. Insurance companies typically manage employer-specific plans, which are negotiated with the employers concerned and cover all people employed by them. They are also active in offering personal pension plans. Multi-employer pension funds are created as memberowned mutual companies and cover industry-wide plans. Although they have different ownership structures, multi-employer pension funds and life insurance companies are 
subject to identical accounting, reporting and other regulatory rules and there is fierce competition among them.

Corporate or single-employer pension funds cover the employees of single companies. They play a small and declining role. Many of them are actually run-off schemes, having been closed to new members and even to new contributions.

Banks play a small part in the second pillar but have a stronger presence in the third pillar. However, they are not allowed to offer insurance products, such as life annuities. With personal pension plans becoming more popular, the part of pension assets managed by banks has been growing. Also, as mentioned earlier, a significant part of pension saving takes place through the supplementary pension plans that manage nearly a quarter of the accumulated assets.

Table 2: Assets of pension institutions, 2005

\begin{tabular}{l|c|c}
\hline Pension institution & DKK billion & Percent of total \\
\hline Life insurance companies & 953 & 44.2 \\
Multi-employer pension funds & 381 & 17.7 \\
Company pension funds & 42 & 1.9 \\
Banks & 298 & 13.8 \\
ATP & 365 & 16.9 \\
SP & 51 & 2.5 \\
LD & 58 & 3.0 \\
\hline Total & 2,154 & 100.0 \\
\hline Total in percent of GDP & $138.4 \%$ & \\
\hline \multicolumn{2}{c}{ Source: Danish FSA }
\end{tabular}

There is considerable concentration in the sector, although this declined in recent years as a result of new entry. In 2005 the top five institutions had a market share of 60 percent, and the top 10 as much as 79 percent. However, the Herfindahl Index of concentration equaled 854 in 2004, having fallen from 1267 in $1995{ }^{1}$

\section{INCOME STATEMENTS AND BALANCE SHEET COMPOSITION}

This section reviews the income statements and the composition of liabilities and assets of pension institutions from 2000 onwards. This is essential for understanding the use of derivatives to achieve a better matching of assets and liabilities.

Future pension obligations are by far the most important liability on the balance sheets of pension institutions. These obligations were - in an accounting sense - not very sensitive to short term market fluctuations until the requirement to mark liabilities to market was introduced in 2003. However, the real economic sensitivity to changes in interest rates has always been substantial. With the embedded options stemming from the interest rate guarantees and other specific policy terms, together with more frequent valuation at market rates, changes in market rates now have a large impact on liabilities and required provisions.

${ }^{1}$ Andersen and Skjodt 2006 
Interest rate guarantees were introduced on new policies from the early 1980 s. $^{1}$ The guaranteed interest rate was to some extent linked to the maximum technical discount rate used in the actuarial calculations of liabilities, and was set at 4.5 percent in 1982. New EEC insurance directives were implemented in Denmark in 1994, causing the guaranteed interest rate on new policies to be reduced to 2.5 percent and in 1999 it was reduced to 1.5 percent.

Table 3: Pension Liabilities Distributed on Interest Rate Guarantee Levels

\begin{tabular}{l|c|c|c|c}
\hline & None & 0 to 2 percent & 2 to 4 percent & Over 4 percent \\
\hline Life insurance companies & $3 \%$ & $25 \%$ & $20 \%$ & $52 \%$ \\
General Pension funds & $2 \%$ & $12 \%$ & $31 \%$ & $55 \%$ \\
\hline
\end{tabular}

Source: Danish FSA

As table 3 shows more than 50 percent of the accumulated liabilities of Danish pension institutions had a guaranteed interest rate of more than 4 percent $^{2}$. Furthermore, these American type guarantees could be exercised at any point before or at maturity, which added significantly to the provisions required to cover the obligations. In 1994, when the maximum guaranteed interest rate was lowered to 2.5 percent, most pension institutions also took the opportunity to switch to European type guarantees, which can only be exercised at maturity. Therefore the liabilities have a long duration and the composition is very difficult to adjust to changing investment return expectations, because policies already written cannot be changed and new contributions paid into old policies, under the terms of those policies, continue to be covered by the original guarantees throughout the life of the contract.

The state of the liabilities is of course mirrored in the provisions required to cover future obligations. With falling interest rates and decreased mortality ${ }^{3}$ the provisions have increased considerably over the past few years, putting pressure on investment returns and squeezing solvency.

Table 4: Pension Obligations Return on investments and solvency ratio, 2000 - 2005

\begin{tabular}{l|c|c|c}
\hline & $\begin{array}{c}\text { Provisions for future } \\
\text { pension obligations } \\
\text { (annual change) }\end{array}$ & $\begin{array}{c}\text { Return on investments } \\
\text { (after tax) }\end{array}$ & $\begin{array}{c}\text { Solvency ratio } \\
\text { (Buffer Capital, } \\
\text { weighted Average) }\end{array}$ \\
\cline { 2 - 4 } & \multicolumn{3}{c}{} \\
\hline 2000 & 7.9 & Percent & 4.2 \\
2001 & 3.5 & 4.95 & 2.4 \\
2002 & 6.0 & -1.2 & 2.2 \\
2003 & 7.9 & 1.71 & 2.6 \\
2004 & 11.4 & 6.05 & 2.7 \\
2005 & 15.7 & 9.11 & 2.6 \\
\hline
\end{tabular}

Source: Danish FSA

\footnotetext{
${ }^{1}$ This practice was also followed in several other countries in continental Europe. The Danish pension institutions were not unique in offering these guarantees, although the size of the Danish market may have been much greater, relative to GDP, than in any other country.

2 The majority of these carry a guaranteed interest rate of 4.5 percent.

${ }^{3}$ Like most European pension institutions the Danish pension sector has also had to adjust provisions to allow for the fact that policy holders are living longer than originally projected.
} 
Bonds have always been the main investment asset for the Danish pension sector with heavy emphasis on domestic, callable mortgage bonds. Even though such mortgage bonds have a maturity of up to 30 years their callable nature results in a significantly shorter effective duration especially in an environment of generally falling interest rates ${ }^{1}$. Because the effective duration of Danish non-government bonds is extremely affected by the prevailing interest rate environment, pension institutions have been adding duration by expanding their portfolio of foreign - mainly euro denominated - bonds since the turn of the century ${ }^{2}$. This has of course also increased their exposure to global market fluctuations.

The 1990s saw a deregulation of investment rules and thereby allowed pension institutions to place a larger part of their funds in equities ${ }^{3}$. But since the turn of the century roughly two thirds of equity investments have been foreign. As can be seen in Table 5, this has introduced significant fluctuations in investment returns.

Comparing return on investments to the growth rate of provisions the mismatch between assets and liabilities from 2000 - 2002 becomes evident. Provisions were growing far more than investment returns could cover, leaving the Danish L \& P sector with the choice of either absorbing the losses by depleting capital reserves, thereby dangerously lowering solvency, or taking measures to bridge the gap between assets and liabilities.

Table 5: Asset Allocation, DKK billion and percent, 1999 - 2005

\begin{tabular}{l|c|c|c|c|c|c|c|c}
\hline & \multicolumn{2}{|c|}{1999} & \multicolumn{2}{c|}{2001} & \multicolumn{2}{c|}{2003} & \multicolumn{2}{c}{$2005 / 1$} \\
\cline { 2 - 9 } & DKK & $\%$ & DKK & $\%$ & DKK & $\%$ & DKK & $\%$ \\
\hline Land and buildings & 59.7 & 8 & 60.4 & 7 & 72.6 & 7 & 92.6 & 7 \\
Subsidiary and associated companies & 21.4 & 3 & 26.4 & 3 & 11.7 & 1 & 10.3 & 1 \\
Danish Equity & 104.4 & 14 & 84 & 10 & 51 & 5 & 78.1 & 6 \\
Foreign Equity & 169.2 & 22 & 146.4 & 17 & 118.7 & 12 & 209.5 & 16 \\
Bonds & 409.9 & 54 & 534.5 & 62 & 706.5 & 71 & 794.6 & 62 \\
Other Investments & 17 & 2 & 30.4 & 4 & 34.8 & 4 & 25.4 & 2 \\
Derivatives acquired for ALM hedging & & & & & & & 67.9 & 5 \\
\hline Total & 762.6 & 100 & 874.9 & 100 & 995.3 & 100 & $1,278.4$ & 100 \\
\hline
\end{tabular}

Notes and Source: Danish FSA.

/1 The numbers before and after 2005 are not comparable. Reporting of investments in bonds, mortgages, cash and term deposits as well as derivatives changes from 2005. Derivatives are before 2005 included in the relevant asset category. From 2005 derivatives acquired for ALM hedging purposes are recorded as a separate category, while derivatives acquired to gain non ALM related exposures still are included in the relevant asset category.

\footnotetext{
${ }^{1}$ For a description of the Danish Mortgage system see Ladekarl (1998) and Nykredit (2005).

2 The duration of Danish bond holdings in December 2002 was only about 5.4 years, whereas the duration of euro bond holdings was as high as 28.8 years. Source: Nykredit Markets (2003).

${ }^{3}$ Generally pension institutions can now hold up to 50 percent of their investment assets in equity, whereas companies with high solvency can hold up to 70 percent in equity.
} 
Figure 2: Assets, 1998 to 2006 ( $1^{\text {st }}$ half $)$

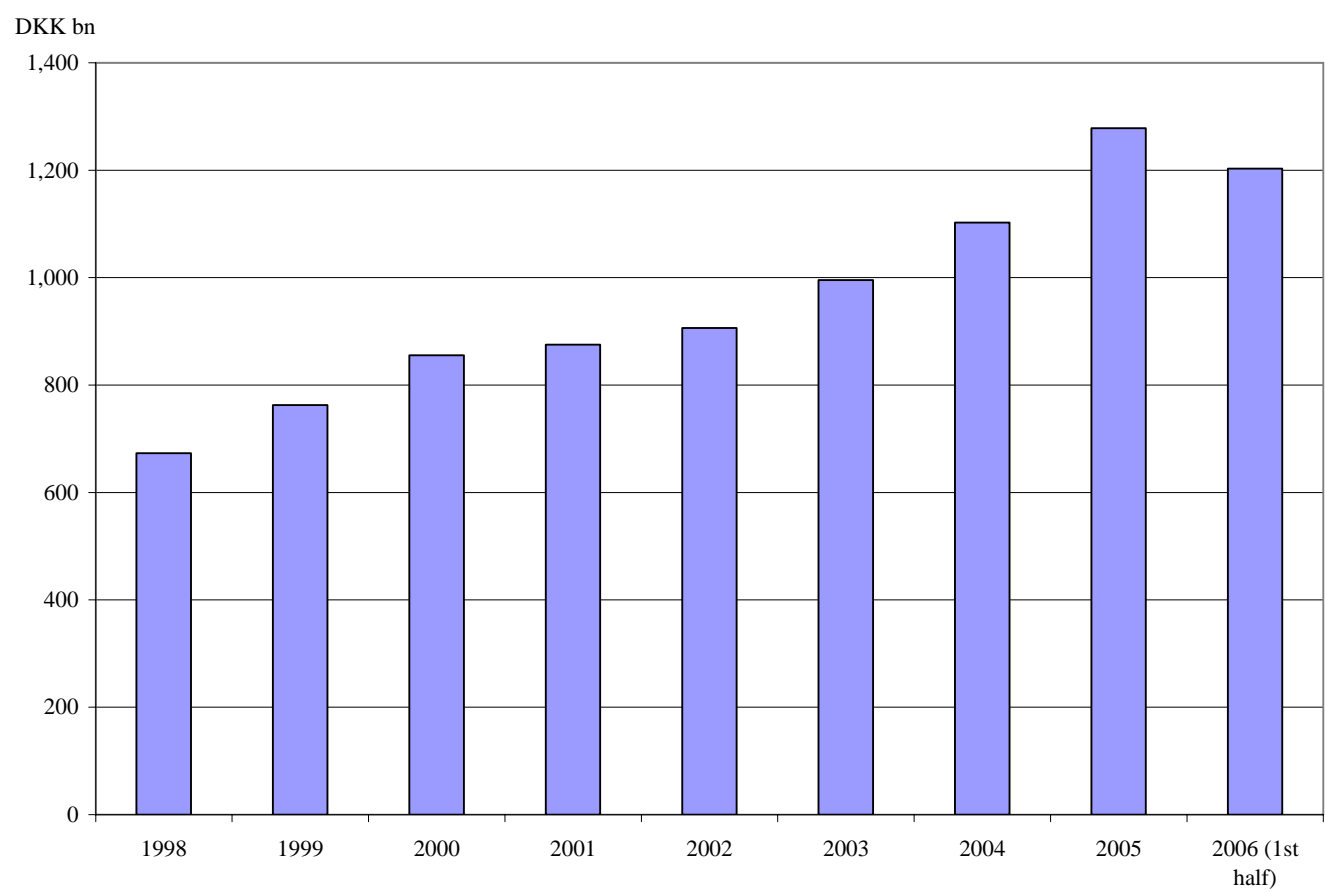

Table 6: Return on Investments, percent, 1998 - 2004 (old accounting standards)

\begin{tabular}{lrrrr|r|r|r|r}
\hline & \multicolumn{1}{c}{1998} & \multicolumn{1}{c}{1999} & \multicolumn{1}{c}{2000} & \multicolumn{1}{c}{2001} & \multicolumn{1}{c}{2002} & \multicolumn{1}{c}{2003} & \multicolumn{1}{c}{2004} \\
\hline Real Estate & 9.8 & 11.0 & 10.9 & 17.3 & 11.8 & 7.2 & 12.0 \\
Subsidiaries & 3.3 & 14.5 & 9.7 & -0.8 & -2.3 & 1.0 & 5.2 \\
Equity, domestic/1 & -4.8 & 24.3 & 23.8 & -15.9 & -20.5 & 30.5 & 25.8 \\
Equity, foreign & 15.7 & 71.4 & -5.9 & -19.9 & -30.1 & 16.3 & 9.3 \\
Bonds, domestic/2 & 10.2 & 1.5 & 10.2 & 9.5 & 11.5 & 4.9 & 7.7 \\
Bonds, foreign & 9.7 & 0.8 & 12.5 & 7.4 & 10.1 & 5.6 & 10.4 \\
\hline Total & 8.1 & 15.4 & 6.5 & -1.8 & 1.5 & 7.8 & 10.6 \\
\hline
\end{tabular}

Notes and Source: Danish FSA

/1: Excluding private equity.

/2: Excluding index-linked bonds.

Table 7: Return on Investments, percent, 2003 - 2005 (new accounting standards)

\begin{tabular}{lc|c|c}
\hline & 2003 & 2004 & 2005 \\
\hline Real Estate & 7.2 & 12 & 23 \\
Subsidiaries & 1 & 5.2 & 2.3 \\
Equity, domestic & 30.5 & 25.8 & 47.2 \\
Private equity, domestic & 9.1 & 5.3 & 26.7 \\
Equity, foreign & 16.3 & 9.3 & 24.2 \\
Bonds & 5.3 & 8.7 & 6.8 \\
Mortgages & 7.2 & 6.9 & 4.5 \\
Other financial investment assets & -0.1 & 43.9 & 25.6 \\
\hline Total & 7.8 & 10.6 & 13.9 \\
\hline
\end{tabular}

Source: Danish FSA 


\section{REGULATORY FRAMEWORK}

The regulatory framework surrounding the pension sector has always focused on the ability of individual pension institutions to fulfill their future pension obligations. Pension institutions have two main sources of capital for absorbing losses without affecting the guaranteed benefits to policyholders: the collective bonus reserves that represent the undistributed profits that belong to policyholders; and own equity funds (paid up capital and retained earnings) that belong to the owners of pension institutions. The solvency ratio measures the ratio of own funds to the minimum capital requirement and is a basic indicator of solvency. The collective bonus reserves also provide an indication of the ability to absorb losses.

Prior to 2003 neither of these measurements took the risk profile of each pension institution into account. It was not until 2003 that it became mandatory to use mark-tomarket asset valuations. ${ }^{1}$ Considering the growing exposure to global markets and the potential impact of adverse market conditions, there was a need for the Danish FSA to find new ways to look at financial strength and capital requirements. The Danish FSA decided to follow the stress-test route through a so-called "traffic light" system.

\begin{tabular}{|c|c|c|c|}
\hline & \multicolumn{3}{|c|}{ Number of Institutions } \\
\hline & Red Light & Yellow Light & Green Ligh \\
\hline 2001 & 1 & 40 & 49 \\
\hline 2002 & 2 & 11 & 58 \\
\hline 2003 & 0 & 2 & 66 \\
\hline 2004 & 0 & 6 & 59 \\
\hline 2005 & 0 & 6 & 59 \\
\hline
\end{tabular}

Source: Danish FSA

The traffic light system was introduced in 2001. It requires pension institutions to report the impact on capital reserves and future pension obligations of two different market scenarios ${ }^{2}$. If the institution is not able to maintain the minimum required solvency under the moderate (red) scenario, it will get a red light from the FSA. Same mechanism applies to the extreme (yellow) scenario, and either the red or yellow light will result in further inspections by the FSA and an increase in capital may be required. If a pension institution is able to withstand both scenarios it gets a green light. Not only does the traffic light system incorporate market risk sensitivity into the solvency assessment, but it also looks at both sides of the balance sheet, where a lot of the problems arose during the perfect storm of 2001/2002 as illustrated by the large number of institutions in Red or Yellow light during those years (Table 8).

\footnotetext{
${ }^{1}$ A discussion of the evolution of prudential regulation and risk-based supervision of pension institutions in Denmark is provided in Andersen and Skjodt (2006) and Van Dam and Brink Andersen (2006).

${ }^{2}$ Red scenario: interest rate change of 0.7 percent, equity price fall of 12 percent, real estate price fall of 8 percent in addition to credit -, exchange rate - and counterpart - related losses.

Yellow scenario: interest rate change of 1.0 percent, equity price fall of 30 percent, real estate price fall of 12 percent in addition to credit -, exchange rate - and counterpart - related losses.
} 
The traffic light system focuses on measuring the impact of changes in interest rates and asset prices on the financial situation of a pension institution. Other changes in the regulatory framework have addressed the measurement of liabilities and the treatment of different cohorts of policy holders by age or by type of guarantee. After long deliberations between the regulators and industry practitioners, several changes have been introduced. Pension institutions are now required to undertake a decomposition of their technical provisions by the level of guaranteed interest rate. They are also required to measure their pension and insurance liabilities by using a zero-coupon yield curve that is published daily by the Danish central bank. In addition, pension institutions must report the mortality tables they use for determining their actuarial liabilities. Finally, they must stipulate very clearly their policies of distributing profits between shareholders and policy holders and among different categories of policy holders.

\section{THE PERFECT STORM}

Up until 2000 it seems as if pension institutions only looked at the financial risks on the asset side of the balance sheet. The market risks related to the liability side, i.e. interest rate guarantees and other embedded options, were neither priced nor hedged. The occasional worries about the ticking guarantee bomb were easily put to rest by the highly positive market performance that ensured ample asset cushions to support the guarantees. Global interest rates had been slowly falling for more than 15 years and equity prices rising - especially in the late 1990s - and the Danish pension sector generated a high return on investments (Table 9).

However, the financial climate changed dramatically in 2001 following the bursting of the high-tech bubble. Like most pension funds in developed countries the Danish pension sector was hit in several areas:

- The significant fall in nominal interest rates brought the interest rate guarantees in the money, which exposed pension institutions to substantial losses, capital drainage and potential solvency problems.

- While the falling interest rates meant a gain on the bond portfolio, this was not enough to cover the increased provisions. Since assets, consisting largely of domestic callable mortgage bonds, were far less sensitive to interest rate movements than liabilities, the gap between the two sides of the balance sheet widened considerably.

- The worst hit though came from the collapse of global equity prices, which in 2001 turned total investment returns negative. A repeat of this result in 2002 was only prevented by a large return on bonds (Figure 3). 
Figure 3: Equity and fixed income markets: 1998 to 2006

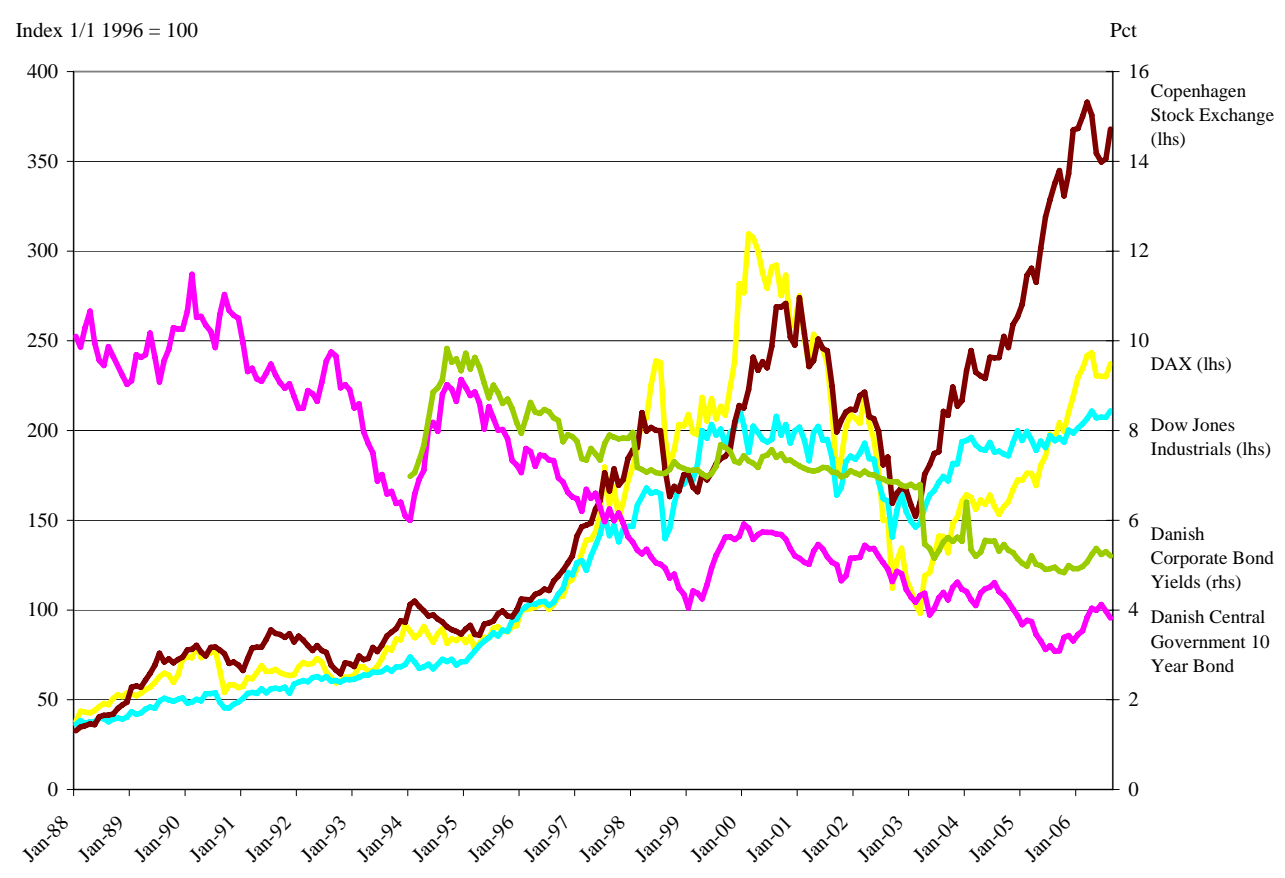

Source: Bloomberg

These events coincided with the introduction of new accounting rules, requiring more frequent and mark-to-market valuation of the balance sheet, and implementation of the traffic light system, which also helped underscore the difficult situation of the pension sector.

Table 9: Return on Investments for Life Insurance Companies and General Pension Funds

\begin{tabular}{l|c|c|c|c|c|c}
\hline & 2000 & 2001 & 2002 & 2003 & 2004 & 2005 \\
\hline Return on investments before tax & 5.65 & -1.63 & 1.77 & 6.86 & 10.40 & 14.25 \\
Return on investments after tax & 4.95 & -1.20 & 1.71 & 6.05 & 9.11 & 12.46 \\
\hline
\end{tabular}

Source: Danish FSA

The Danish experience highlights the potential advantages of introducing such regulatory and accounting changes during times where financial markets are calm. The combination of turbulent financial markets and dramatic rule changes may force individual institutions to implement myopic solutions to survive to the detriment of longterm performance maximization.

\section{THE GROWING USE OF DERIVATIVES}

The impact of the perfect storm illustrated an essential point about the balance sheet of the Danish pension institutions, namely the mismatch between the two sides. Getting a better match on the balance sheet involves managing both liabilities and assets, but since little can be done in the short run to directly change the structure of liabilities 
that consist of future pension obligations, the focus was by necessity on optimizing asset allocation policies and on a more intensive use of hedging instruments.

Even though asset allocation has been changed by, for example, the significant addition of foreign bonds with longer duration, the biggest impact was achieved by the growing use of derivatives to hedge against potential risks, which, as Figure 4 illustrates, has grown virtually exponentially since 2000 .

Figure 4: Insurance Companies and Pension Funds use of Derivative Contracts /1

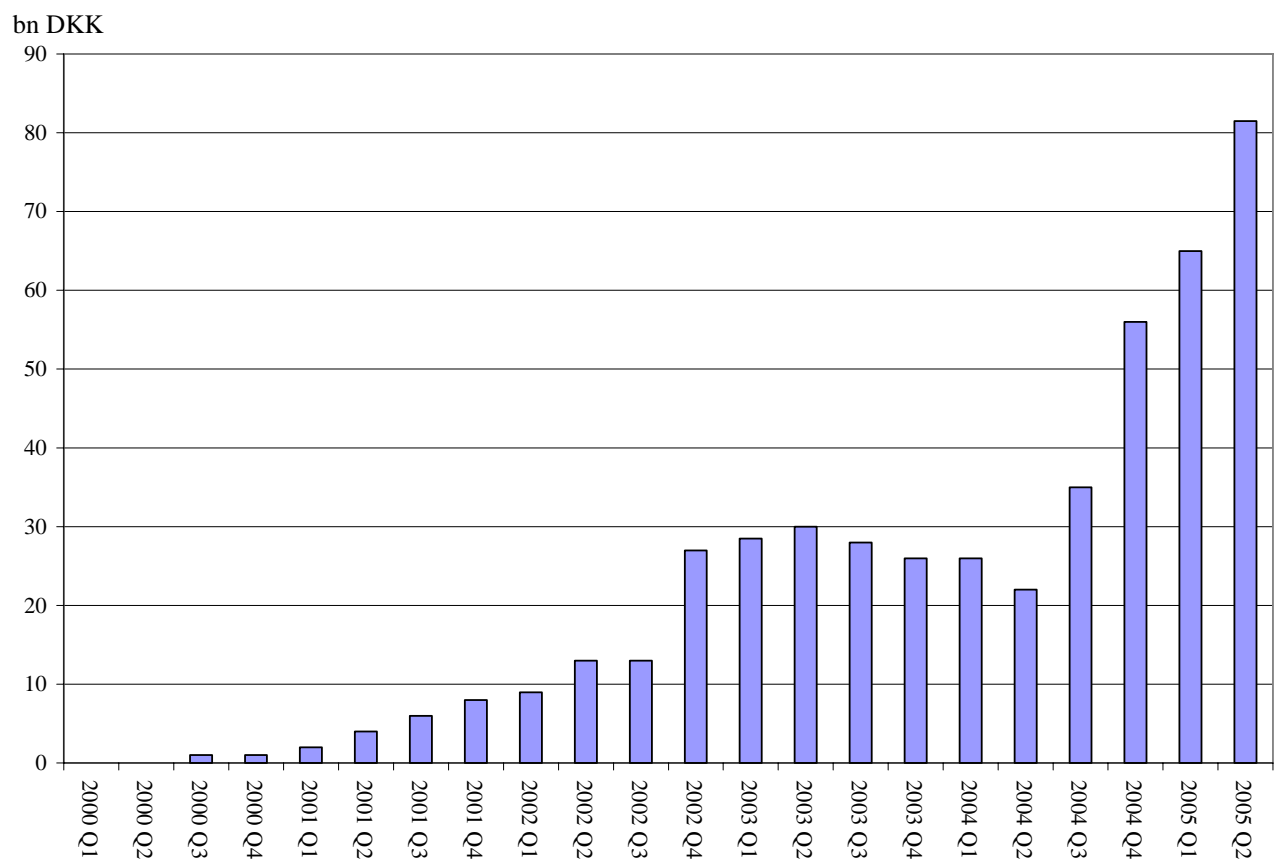

Source and Notes: Danish FSA

/1: The numbers do not include the substantial amount of written options the institutions carry on their balance sheets from investing in callable mortgage bonds.

The major areas of market risk exposure of the Danish pension sector are:

- Interest rates are without comparison the largest risk factor, because of the interest rate guarantees on the liability side and the lack of interest rate sensitivity on the asset side.

- $\quad$ Equity prices have also proven to be a considerable risk factor. Most Danish pension institutions seized the opportunities arising from deregulation to increase their holdings of equities, especially foreign, thus leaving them exposed to the more volatile equity market.

- Currency exposure: Investments in foreign assets (especially foreign equities) are usually not hedged back to Danish Kroner. In the long run the expected return on this embedded currency exposure is zero, implying any gains and losses will even out over time. However, in the short to medium term currency fluctuations can be a 
major component of the returns (measured in DKK) as well as the risk of international investments.

The accounting implications of the exposure to both interest rate and equity risk have been further accentuated by the implementation of frequent mark-to-market valuations as even short-term market volatility has an immediate impact on the balance sheet.

These different kinds of risk exposure can in general be hedged through the use of derivatives. The most common derivatives used by Danish pension institutions to hedge interest rate risk are interest rate swaps, swaptions (i.e., options to enter into swaps) and constant maturity swap (CMS) floors.

The simplest of these instruments is the interest rate swap. A swap is an instrument where payment streams are exchanged. An interest rate swap typically lets the counterparts trade fixed interest rate payments for floating interest rate payments, thereby hedging the receiver of the fixed payments against interest rate fluctuations, in this case more specifically interest rate decreases.

A swaption is an option to buy or sell a swap at a specific price at a specific point in time. In this case, as before, bought swaptions are used as a shield against a fall in interest rates. For example, the pension institution buys a swaption that allows it to enter an interest rate swap to receive fixed payments, if the interest rate falls below a certain level, thereby ensuring a minimum payment.

A CMS floor is a further bundling of the instruments mentioned above. It is a series of interest rate swaps that expire at fixed intervals. The fixed interest rate of the swap is reset at each expiration point and is usually tied to an underlying asset with a longer maturity than the contract itself. Furthermore, the CMS floor contains a restriction as to how low the fixed interest rate can get, thereby putting in a floor that limits the potential decrease in the fixed payments.

The derivative most commonly used to hedge or gain equity risk exposure is a futures contract. Futures contracts are standardized, exchange-traded contracts to buy or sell an underlying asset, in this case equity, at a specific price at a future date.

Which instrument is used depends on several factors:

- Hedging strategy

- Contract pricing

- Market depth

- Counterparty credit risk exposure

- Regulatory requirements

- Experience

Derivatives are not a new instrument for the Danish pension sector, which is very familiar with options through the vast portfolios of callable mortgage bonds and because 
of restrictions on the portion of assets in foreign denomination ${ }^{1}$ which are managed through the use of FX derivatives, predominantly FX forward contracts ${ }^{2}$. However, it was not until late 2001, when the financial solvency situation was at its gravest, that derivatives became the risk hedging instrument of choice.

\section{THE FINANCIAL IMPACT OF DERIVATIVES}

The financial impact of the use of derivatives can - at least partially - be shown by analyzing the aggregate interest rate sensitivity of the assets and liabilities of pension institutions before the use of derivatives and then looking at the net aggregate sensitivity after their use.

As mentioned above, the Danish FSA performs stress tests on the balance sheets of the individual pension institutions measuring the effect of stipulated changes in interest rates. Four values are used: $+1,+0.7,-0.7$ and -1 percentage point. The following figures are constructed from these discrete data-points assuming a continuous non-linear relationship between the different discrete points. ${ }^{3}$

The interest rate sensitivity of the liabilities and the assets are first discussed, followed by the combined interest rate sensitivity of assets and liabilities. Then the interest rate sensitivity of derivatives is shown and finally the overall interest rate sensitivity of the total portfolio, including derivatives, is set out. This allows a fuller grasp of the transformation in the pay-off curve that was achieved by the use of derivatives.

\footnotetext{
${ }^{1}$ To be more exact, 80 percent of the assets reserved to cover liabilities must be in DKK.

${ }^{2}$ A FX Forward contract is a contract to deliver or receive an amount of foreign currency at a future point in time. The price of a forward contract is the sum of the spot FX price plus the forward points. The forward points reflect the interest rate differential between the currencies exchanged at the time of exchange.

${ }^{3}$ This is an approximation which is unlikely to hold in reality. The non-linear nature of the derivatives on both the asset and liability side as well as the exotic nature of some of the bought/sold derivatives may result in discreet jumps in the sensitivity to interest rate changes. No data is available to support or refute these observations. However, it illustrates a general weakness in stress tests of this nature: A firm can target the effect of a specific interest rate change in a cheap way by buying protection for that particular point on the curve, but retaining - or even adding on to - risk just outside the point.
} 
Figure 5: Interest rate sensitivity of liabilities, 2002 to mid 2006

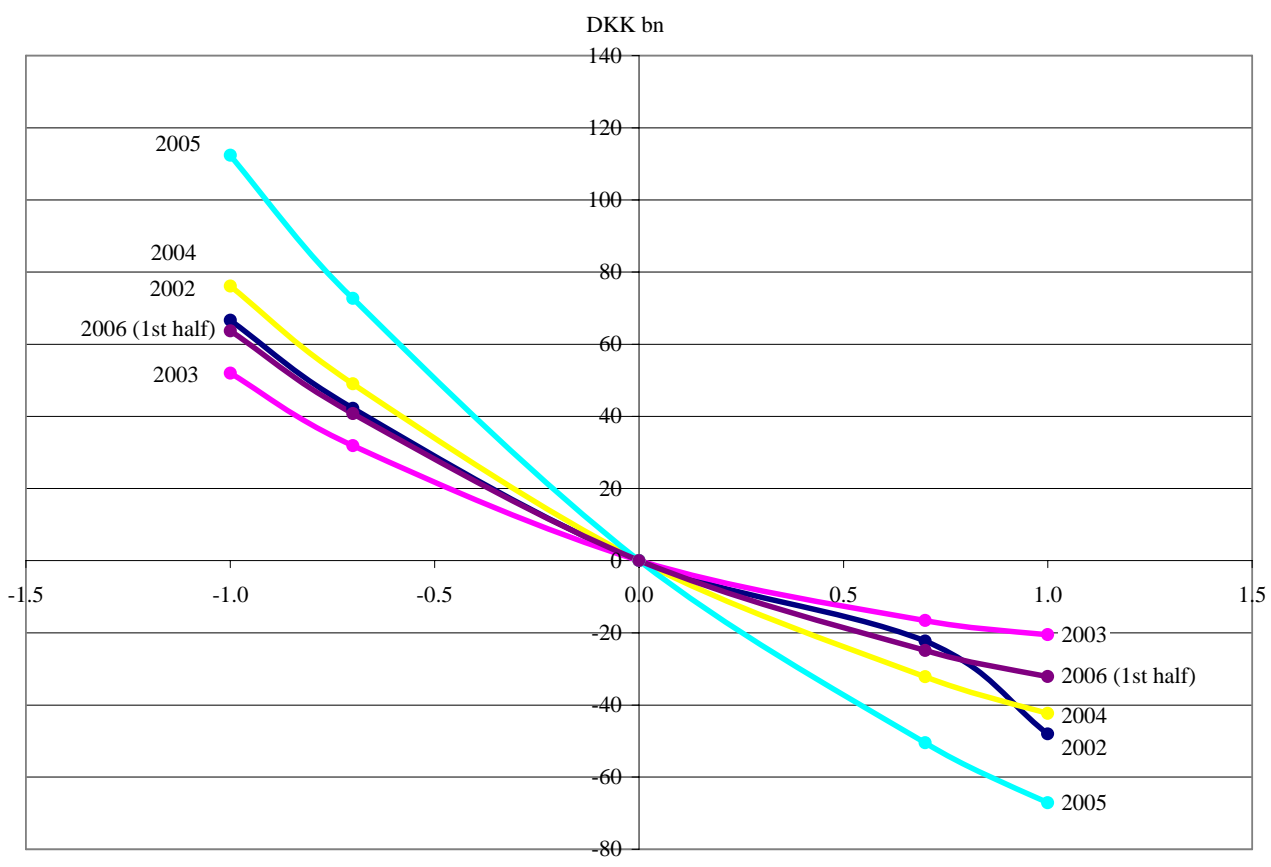

Table 10: Interest Rate Sensitivity of Liabilities

\begin{tabular}{|c|c|c|c|c|c|}
\hline & \multicolumn{4}{|c|}{ Interest Rate Change } & \multirow{2}{*}{$\begin{array}{l}10 \text { Year government bond } \\
\text { yield (end of period) }\end{array}$} \\
\hline & $-1 \%$ & $-0.7 \%$ & $+0.7 \%$ & $+1 \%$ & \\
\hline & \multicolumn{4}{|c|}{$D K K$ bn } & Percent \\
\hline 2002 & 66.0 & 42.2 & -22.3 & -48.0 & 4.46 \\
\hline 2003 & 52.0 & 31.9 & -16.6 & -20.5 & 4.47 \\
\hline 2004 & 76.1 & 49.0 & -32.2 & -42.3 & 3.85 \\
\hline 2005 & 112.4 & 72.7 & -50.5 & -67.1 & 3.28 \\
\hline 2006 ( $1^{\text {st }}$ half $)$ & 63.7 & 40.8 & -24.9 & -32.1 & 4.12 \\
\hline
\end{tabular}

Source: Danish FSA. Bloomberg (yields)

Figure 5 and Table 10 above shows the interest rate sensitivity of aggregate liabilities and, for reference, the 10 Year government bond yield. Liabilities increase when interest rates go down (the net present value of future payments goes up) and fall when interest rates rise. The effect is not symmetric, however. When rates fall by 1 percentage point, liabilities increase more than they fall when rates rise by 1 percentage point. This asymmetric effect can be attributed to the issued interest rate guarantees that gain in value rapidly when rates fall, while they have no value when rates are increasing from levels well above the guaranteed levels. This effect is visible in all the years illustrated above (2002 to 2006), but it is, as expected, more pronounced the lower the level of market interest rates. In 2005 when rates were at their lowest (see figure 3) the negative impact of a further fall in interest rates was the highest, as many of the issued interest rate guarantees were close to or already in the money. In that year a percentage point drop in interest rates would result in an increase in liabilities of DKK $110 \mathrm{bn}$. 
Figure 6: Interest rate sensitivity of assets, 2002 to Mid 2006

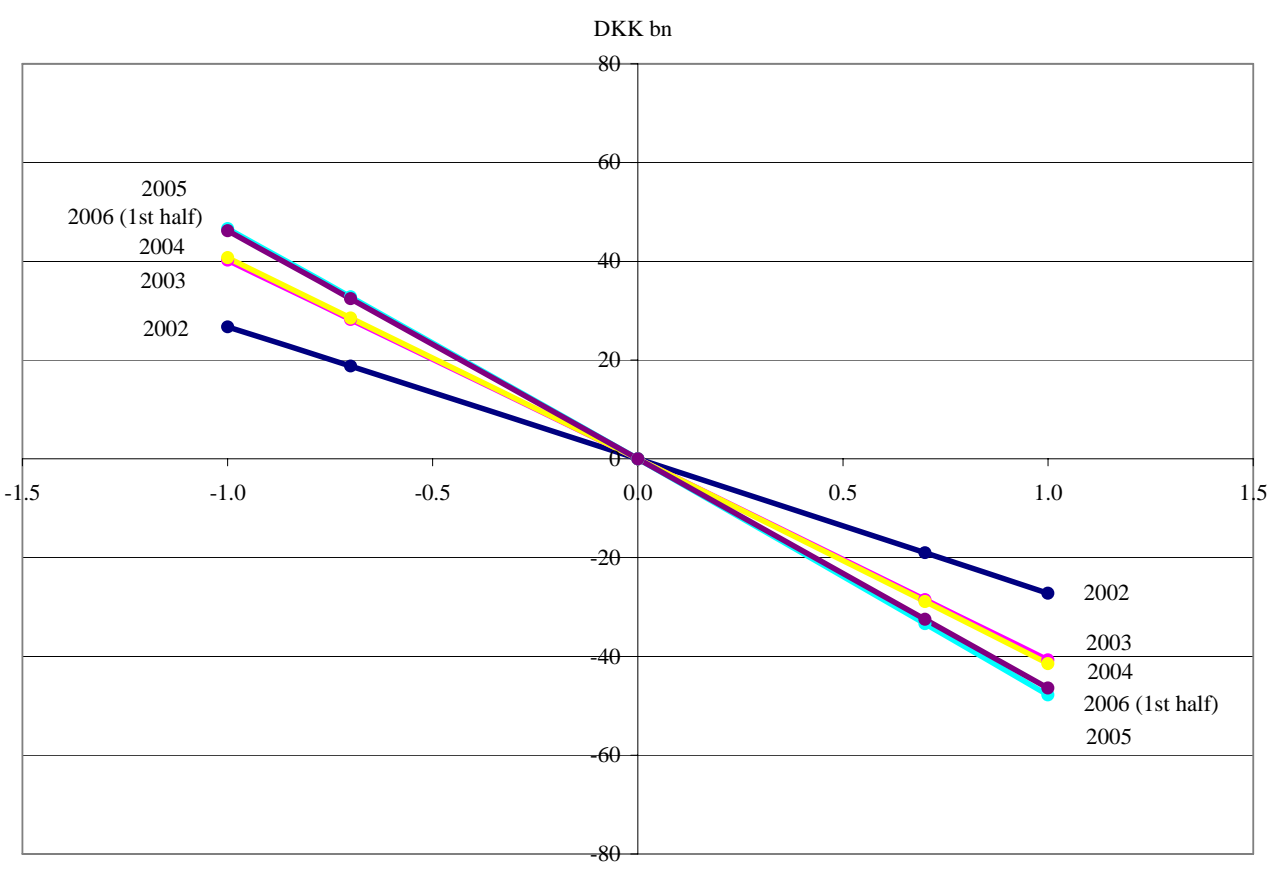

Table 11: Interest Rate Sensitivity of Assets

\begin{tabular}{|c|c|c|c|c|c|}
\hline & \multicolumn{4}{|c|}{ Interest Rate Change } & \multirow{2}{*}{$\begin{array}{c}10 \text { Year government bond } \\
\text { yield (end of period) }\end{array}$} \\
\hline & $-1 \%$ & $-0.7 \%$ & $+0.7 \%$ & $+1 \%$ & \\
\hline & \multicolumn{4}{|c|}{$D K K b n$} & Percent \\
\hline 2002 & 26.7 & 18.8 & -19.0 & -27.2 & 4.46 \\
\hline 2003 & 40.2 & 28.2 & -28.5 & -40.7 & 4.47 \\
\hline 2004 & 40.7 & 28.5 & -28.9 & -41.5 & 3.85 \\
\hline 2005 & 46.6 & 32.8 & -33.4 & -47.8 & 3.28 \\
\hline 2006 ( $1^{\text {st }}$ half $)$ & 46.2 & 32.4 & -32.5 & -46.4 & 4.12 \\
\hline
\end{tabular}

Source: Danish FSA. Bloomberg (yields)

The interest rate sensitivity of assets show in Figure 6 and Table 11 reflects their composition, which is geared toward longer maturity government and mortgage bonds. The positive duration of these assets results in capital gains when rates go down and losses when rates go up. This relationship is observable in the aggregate numbers. The asset side does not show a similar asymmetric response to interest rate changes as the liability side. However, pension institutions invest heavily in callable mortgage bonds. When interest rates fall below a certain level, borrowers refinance their mortgage bonds and deny pension institutions an offsetting gain on the asset side. This particular feature aggravates the problems created by the asymmetric effect on the liability side. It is, therefore, somewhat surprising that the effect shown by the stress test is quite symmetric. ${ }^{1}$ The absolute interest rate sensitivity of assets has in all the years been less than the interest rate sensitivity on the liabilities side, leaving the institutions with a substantial duration gap.

\footnotetext{
${ }^{1}$ This may in part be because the measurement of the impact of the embedded options in mortgage bonds is incomplete. The embedded options in mortgage bonds are expected to result in smaller DKK gains when rates go down by 1 percentage point than the DKK loss when rates increase by 1 percentage point.
} 
Figure 7: Net Interest rate sensitivity without derivatives, 2002 to mid 2006

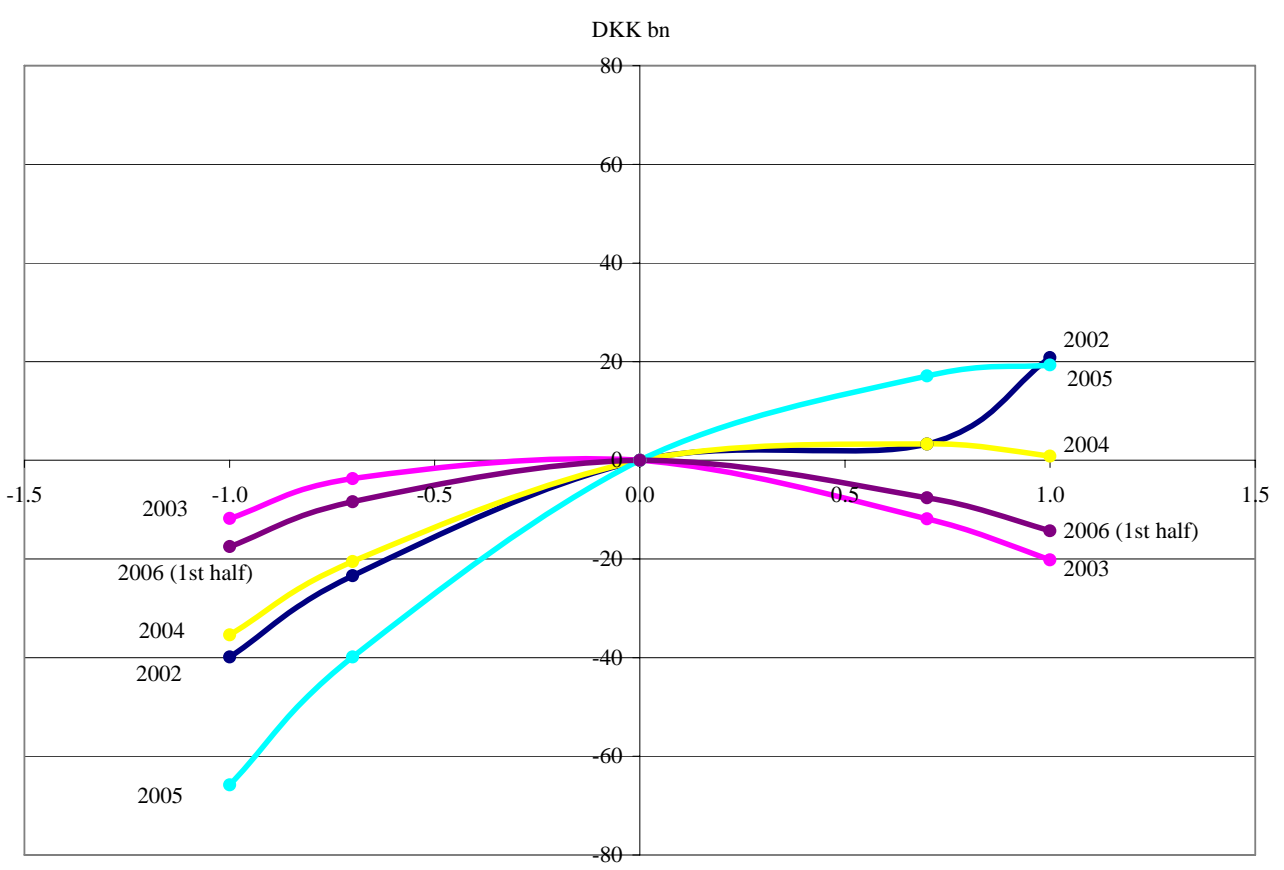

Table 12: Interest Rate Sensitivity Without Derivatives

\begin{tabular}{|c|c|c|c|c|c|}
\hline & \multicolumn{4}{|c|}{ Interest Rate Change } & \multirow{2}{*}{$\begin{array}{l}10 \text { Year government bond } \\
\text { yield (end of period) }\end{array}$} \\
\hline & $-1 \%$ & $-0.7 \%$ & $+0.7 \%$ & $+1 \%$ & \\
\hline & \multicolumn{4}{|c|}{$D K K b n$} & Percent \\
\hline 2002 & -39.9 & -23.4 & 3.3 & 20.8 & 4.46 \\
\hline 2003 & -11.8 & -3.7 & -11.9 & -20.2 & 4.47 \\
\hline 2004 & -35.4 & -20.5 & 3.3 & 0.84 & 3.85 \\
\hline 2005 & -65.8 & -39.9 & 17.1 & 19.3 & 3.28 \\
\hline 2006 ( $1^{\text {st }}$ half $)$ & -17.5 & -8.4 & -7.6 & -14.3 & 4.12 \\
\hline
\end{tabular}

Source: Danish FSA. Bloomberg (yields)

The net interest rate sensitivity of the industry without taking into account positions in derivatives shows for most years a net loss when interest rates fall and a gain when they rise (Figure 7 and Table 12). In other words the liability side effects dominate those of the asset side. In addition, the gains from a 1 percentage point increase in rates are smaller than the losses from a similar reduction in rates, illustrating the compound effect of the asymmetric impact of interest rate changes on both the asset and liability side. In 2003 the pension sector was in a very peculiar situation where interest rate changes in any direction would have resulted in a deterioration of the balance sheet., The net interest rate sensitivity (without derivatives) of the industry as a whole has increased over time as the asset interest rate sensitivity has been unable to keep up with the effect of increased interest rate sensitivities on the liability side increasing the duration gap in the balance sheets. 
Figure 8: Interest rate sensitivity of derivatives, 2002 to mid 2006

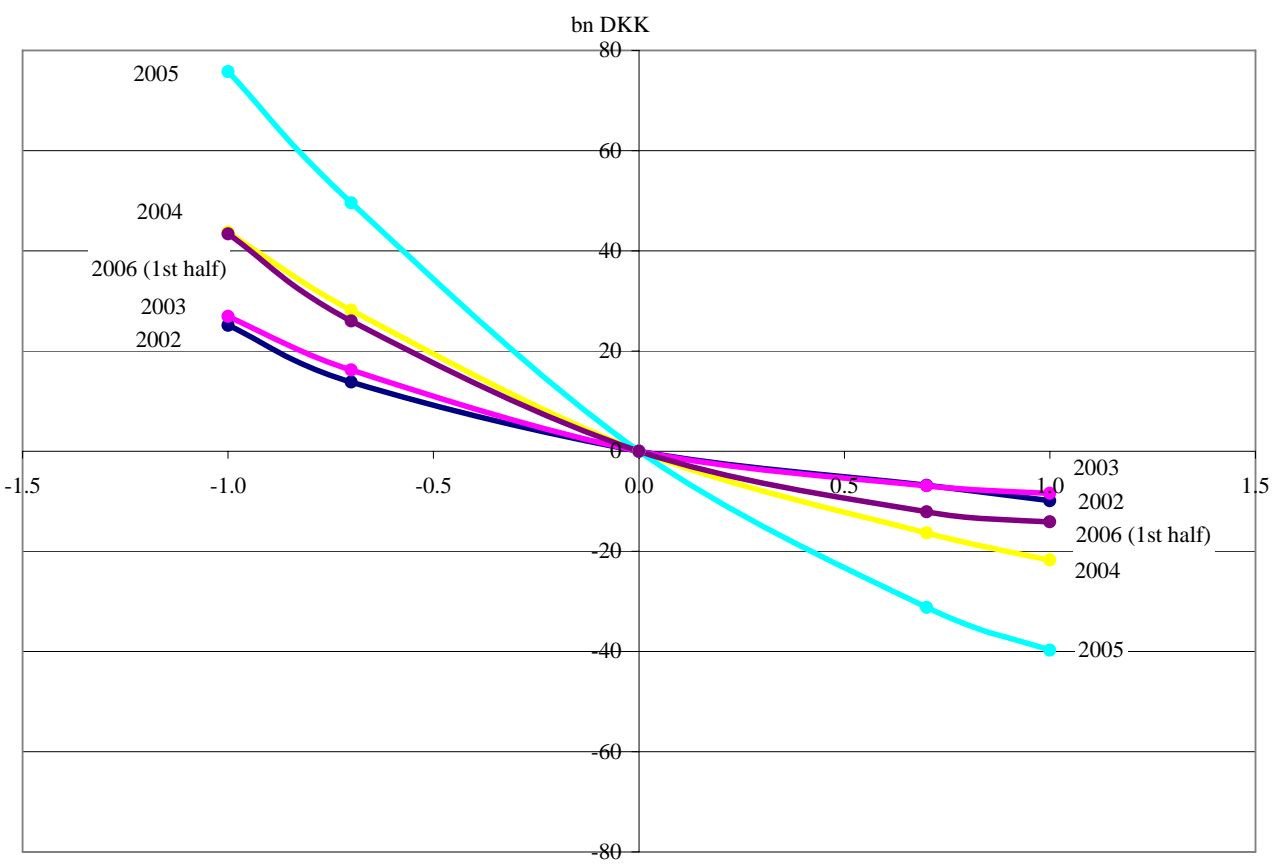

Table 13: Interest Rate Sensitivity of Derivatives

\begin{tabular}{|c|c|c|c|c|c|}
\hline & \multicolumn{4}{|c|}{ Interest Rate Change } & \multirow{2}{*}{$\begin{array}{l}10 \text { Year government bond } \\
\text { yield (end of period) }\end{array}$} \\
\hline & $-1 \%$ & $-0.7 \%$ & $+0.7 \%$ & $+1 \%$ & \\
\hline & \multicolumn{4}{|c|}{$D K K b n$} & Percent \\
\hline 2002 & 25.1 & 13.8 & -6.8 & -9.9 & 4.46 \\
\hline 2003 & 26.9 & 16.2 & -6.9 & -8.4 & 4.47 \\
\hline 2004 & 43.8 & 28.2 & -16.3 & -21.7 & 3.85 \\
\hline 2005 & 75.8 & 49.6 & -31.2 & -39.7 & 3.28 \\
\hline 2006 ( $1^{\text {st }}$ half $)$ & 43.4 & 26 & -12.1 & -14.1 & 4.12 \\
\hline
\end{tabular}

Source: Danish FSA. Bloomberg (yields)

Figure 8 and Table 13 shows the interest rate sensitivity of the derivatives positions. In aggregate the pension sector has in all years used derivates to increase the duration of its assets. As discussed earlier, pension institutions have exchanged floating rate payments for fixed rate receipts in the Euro-swap markets, or bought derivative structures with floors resulting in receipts if rates go below certain levels. The floors (and other similar derivatives) have resulted in asymmetric interest rate sensitivities on the derivatives side. In effect the institutions bought convexity giving them a larger gain when interest rates fall compared to the losses they would suffer when rates go up. For example, in 2005 a 1 percentage point fall in interest rates would have produced a gain from derivatives of DKK 80 billion, whereas a 1 percentage point increase would have resulted in a DKK 40 billion loss. In addition the interest rate exposure from the use of derivatives increased over time, as shown by the successively higher level of losses from a 1 percentage point reduction in rates. 
Figure 9: Net interest rate sensitivity with derivatives, 2002 to mid 2006

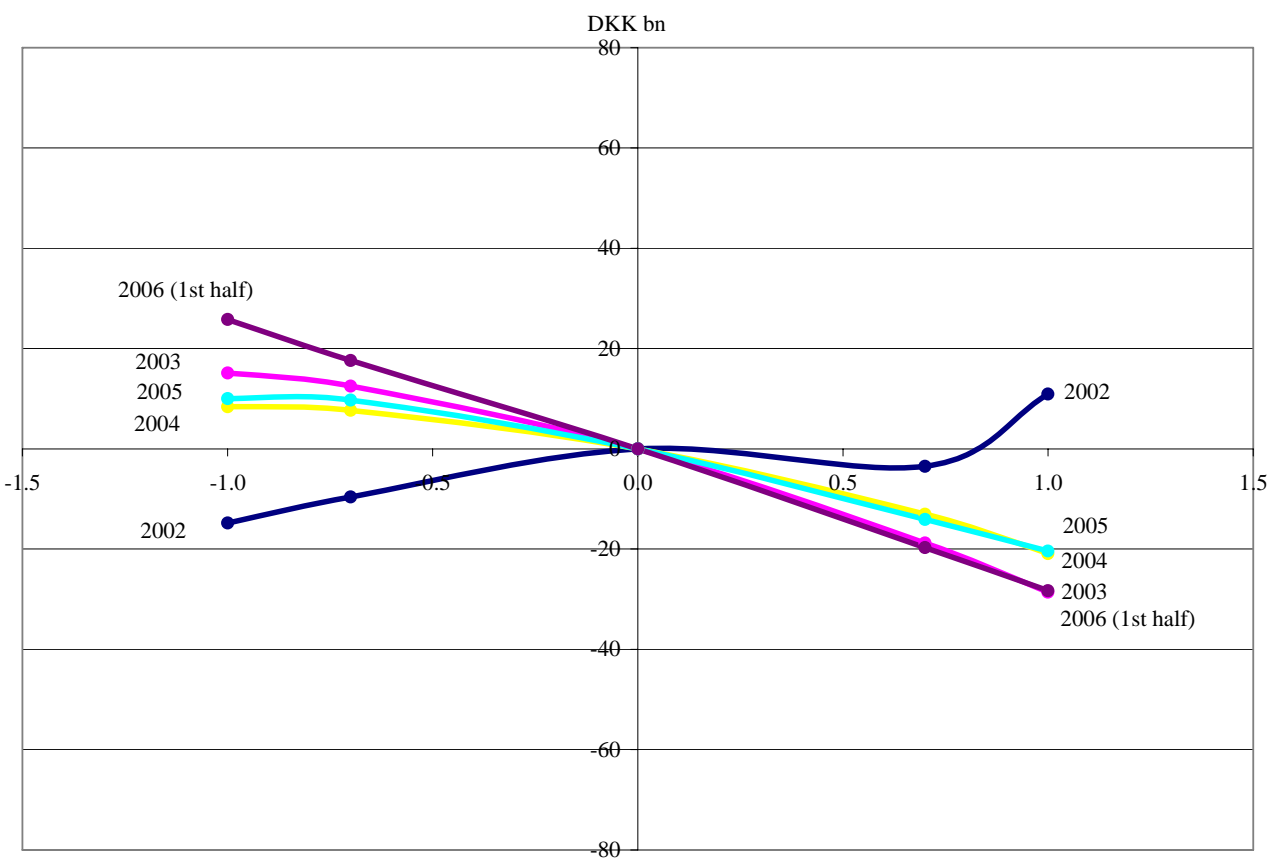

Table 14: Interest Rate Sensitivity With Derivatives

\begin{tabular}{|c|c|c|c|c|c|}
\hline & \multicolumn{4}{|c|}{ Interest Rate Change } & \multirow{2}{*}{$\begin{array}{c}10 \text { Year government bond } \\
\text { yield (end of period) }\end{array}$} \\
\hline & $-1 \%$ & $-0.7 \%$ & $+0.7 \%$ & $+1 \%$ & \\
\hline & \multicolumn{4}{|c|}{$D K K b n$} & Percent \\
\hline 2002 & -14.8 & -9.6 & -3.5 & 10.9 & 4.46 \\
\hline 2003 & 15.1 & 12.5 & -18.8 & -28.6 & 4.47 \\
\hline 2004 & 8.4 & 7.7 & -13.0 & -20.9 & 3.85 \\
\hline 2005 & 10.0 & 9.7 & -14.1 & -20.4 & 3.28 \\
\hline 2006 ( $1^{\text {st }}$ half $)$ & 25.8 & 17.6 & -19.7 & -28.3 & 4.12 \\
\hline
\end{tabular}

Source: Danish FSA. Bloomberg (yields)

The net interest rate sensitivity of the industry in aggregate is illustrated in Figure 9 and Table 14 above. By using derivatives the interest rate risk of the industry has been greatly reduced. Caps have clearly been put in place for a large portion of the industry as there is no difference in the losses sustained in 2003, 2004 or 2005 by a 1 or 0.7 percentage point rise in interest rates. The "normal” relationship between interest rates and gains/losses that would be expected in the balance sheet of an institutional investor has been reestablished: when interest rates go up, capital losses are incurred, while when interest rates go down, capital gains ensue. In other words, the industry has succeeded in being net long duration. ${ }^{1}$ This is the exact opposite of the situation without derivatives, where the effects of the liability side dominated those of the asset side, and the magnitude of change is significantly higher. In other words: derivatives have been used not only to change the risk profile in general but specifically to reduce overall interest rate risk.

\footnotetext{
${ }^{1}$ It can be argued that if taking interest rate risk is not rewarded long term investors should not take any interest rate risk over and above what is needed to hedge their liabilities. If this holds true, the Danish industry has over-hedged, and would be better off not having a net long duration.
} 
Figure 10: Net interest rate sensitivity with and without derivatives, 2003 to 2005

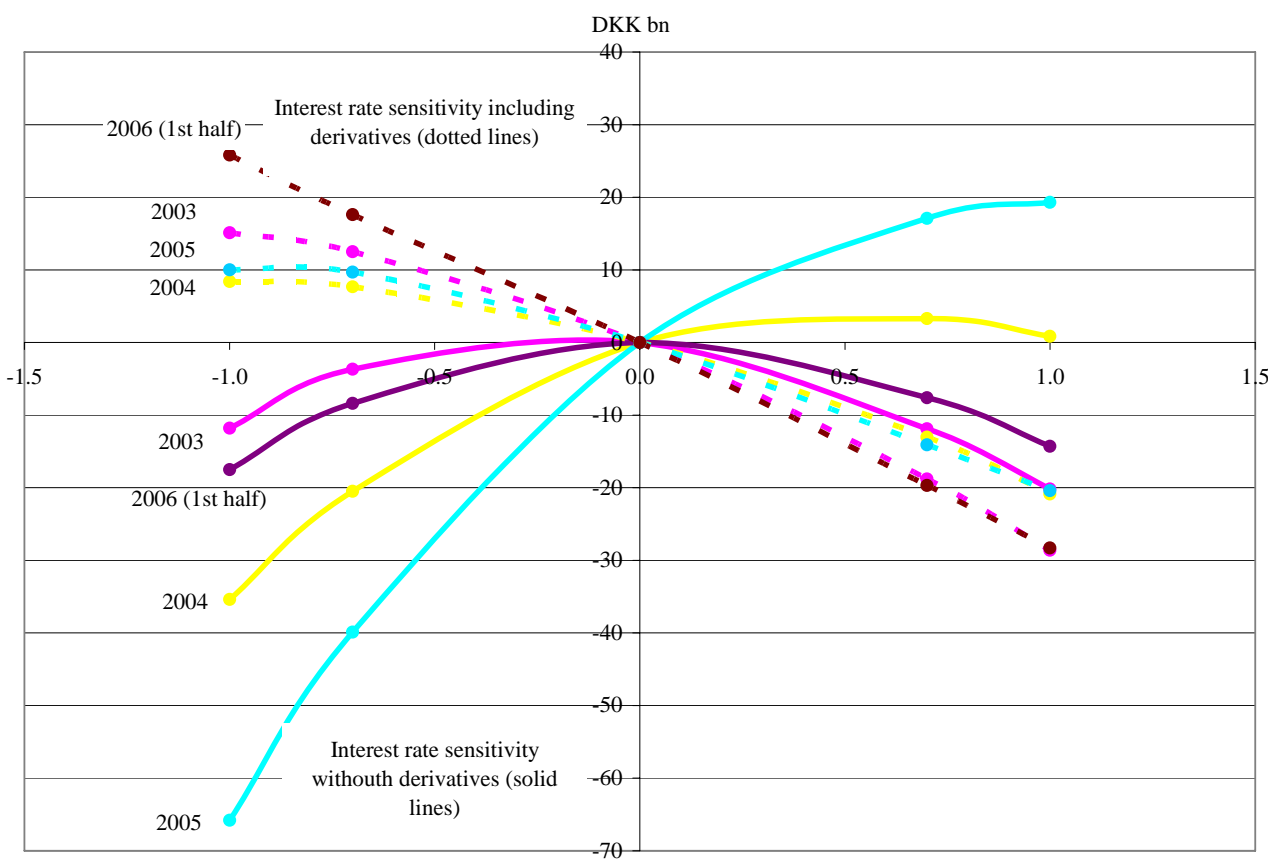

Figure 10 above recapitulates the results of the preceding analysis and shows the combined effect of interest rate changes on the aggregate balance sheet of the industry with and without the use of derivatives for the years 2003 to 2005. It can be clearly seen that the use of derivatives has allowed the industry to completely transform the payoff curve from being negatively affected by interest rate declines to being positively affected. In addition the pension sector as a whole has been able by using derivatives to operate with substantially increased on-balance-sheet interest rate exposures, while protecting itself from the negative effects of interest rate falls through off balance sheet instruments. Through the use of derivatives, the industry has effectively avoided having to renegotiate the guaranteed contracts with policyholders.

The overall net interest rate sensitivity of the industry has been reduced by the use of derivatives. In addition it is much less varying from year to year than the sensitivity without derivatives. The pension sector has used derivatives to lower risk. In addition it has used derivatives as a buffer for the large changes in sensitivities imported from the liability side in particular. This has allowed pension institutions to determine their asset allocation strategies somewhat independently from the liability side, using derivatives to cover any shortfall, and focusing on the residual net exposures. 


\section{CASE STUDIES}

To provide a better picture of the use of derivatives, than what the aggregate numbers presented in the preceding section are able to do, this section covers the individual and very different experience of 3 different Danish pension institutions.

Danish pension institutions were not required until recently to provide any reports on their use of derivatives or their hedging activities. However, some information surfaced - mainly from the companies themselves - that can be used to shed light on different strategies that were used by pension institutions to deal with the financial effects of the perfect storm that hit them in 2001 and 2002. This section reviews the experience of three pension institutions: PFA, ATP and MP, covering respectively a coerced, proactive and passive strategy.

\subsection{PFA: A COERCED STRATEGY}

PFA is one of the largest life insurance companies in Denmark and was hit hard by the perfect storm. PFA has a lot of policies with 4.5 percent guaranteed interest rates on its books and together with the decrease in global interest rates this made the provisions for future obligations soar. The steep drop in equity prices following 9/11 2001 was the straw that broke the camel's back as the loss from equities caused the reserves to fall below the statutory solvency requirement in late 2001. The Danish FSA requested from the PFA to draw up immediately a capital restoration plan.

The plan consisted of two key elements:

- Changing asset allocation by selling foreign equity ${ }^{1}$ and buying foreign bonds with long maturity. This would both limit the risk of further losses on equities and add interest sensitivity to the balance sheet.

- Acquiring a CMS floor option contract ${ }^{2}$ to curb the losses from interest rate decreases and remove some of the convexity of the balance sheet.

Because of these measures PFA's solvency was better in 2002, albeit still on the weak side. The PFA continued to focus on asset/liability management and active asset allocation by further reducing its equity holdings and increasing the interest rate sensitivity of its bond portfolio. In addition the PFA received subordinated loan capital from Danish banks early in 2002. The derivatives hedging strategy was unchanged as the CMS floor option was still running and even contributed positively by DKK 0.9 billion to the 2002 result.

Having gained more experience with derivatives as hedging instruments, but also realizing the costs of this approach, it seems that the PFA in 2003 changed its hedging

\footnotetext{
${ }^{1}$ The foreign equity sold had a value of DKK 21 billion, which amounted to 75 percent of PFA's total equity holdings.

${ }^{2}$ The nominal value of the contract was DKK 50 billion and the strike rate was 5.3 percent, which equals the 4.5 percent guaranteed interest rate plus after revenue tax.
} 
strategy and became more selective and sophisticated. The hedging strategy was also better integrated with the overall investment strategy ${ }^{1}$. Derivatives contributed negatively by DKK 0.7 billion to the 2003 result.

The PFA case illustrates how asset allocation and derivatives have been used in response to a serious crisis. The PFA was under pressure to improve its solvency immediately and had it not been for these drastic measures, it is conceivable that it might not have been able to weather the storm. However, the urgency of the situation also entailed high costs that probably could have been avoided, had the PFA previously acquired derivatives as hedging instruments. As management fought for the survival of the company how blunt or expensive an instrument was in the long run became irrelevant as long as it could help bring the company out of the immediate crisis.

\subsection{ATP: A PROACTIVE STRATEGY}

ATP is the largest supplementary pension administrator and one of the largest pension institutions in Denmark. It has always been on the forefront of financial management. Not being a pension institution in the traditional sense, ATP was not burdened by interest rate guarantees. However, the new accounting rules that required frequent mark-to-market valuation of the balance sheet had daunting prospects for ATP.

ATP began using asset/liability management (ALM) principles for internal purposes as early as 1998, but only with book values. In 2001 the Danish FSA announced the new accounting rules and ATP concluded that the rules would significantly increase the risk of solvency problems as mark-to-market valuations revealed a mismatch between assets and liabilities ${ }^{2}$.

Alleviating the mismatch by active asset allocation, for example by selling shortduration and buying long-duration assets, proved insufficient as the demand for longduration bonds far outweighed the supply ${ }^{3}$. Therefore ATP decided to use derivatives as hedging instruments, more specifically euro interest rate swaps, as the best way to bridge the gap between assets and liabilities. This decision was neither easy nor obvious and it was partially made by the principle of exclusion. The key factors were ${ }^{4}$ :

- The DKK market was too small and without the necessary liquidity. The euro market was the most obvious solution for the volume needed.

\footnotetext{
${ }^{1}$ PFA's 2003 annual report speaks of securing “a better match between assets and liabilities" that "too much hedging can be expensive in terms of forgone income" and "the challenge is to find the right balance between solvency and return to policyholders".

${ }^{2}$ Using market rates ATP estimated that a 1 percent decrease in interest rates would cause provisions for future obligations to increase by DKK 44 billion, but only increase assets by DKK 18 billion leaving a mismatch of DKK 26 billion.

${ }^{3}$ At the time ATP estimated that even if it bought all the outstanding long-duration Danish bonds, it would still not cover the interest rate sensitivity of the liabilities.

${ }^{4}$ Gosvig M., Wind L.
} 
- There would be no currency risk to speak of in holding euro interest rate swaps given the Danish exchange rate regime whereby the DKK is managed in a very narrow band against the Euro.

- Due to operational risk management procedures in ATP it would be a complicated, lengthy and costly process to use anything but plain vanilla derivative instruments, like swaps and futures.

- The futures market lacked the required depth.

- Swaps were seen as more cost efficient than futures and options as they typically have a longer maturity.

Going ahead with its plan in late 2001, ATP acquired a very large euro interest rate swap contract ${ }^{1}$. Because of the size of the deal the acquisition briefly caused interest rates to go up, resulting in an isolated loss on the swap holding of DKK 2.3 billion. In addition ATP increased the interest rate sensitivity of its bond portfolio as much as the market situation permitted.

In 2002 ATP further increased its use of derivatives as it voluntarily complied with the Danish FSA's market valuation reporting requirements, which had to be implemented no later than 2003. It more than doubled its holdings of interest rate swaps, which reduced the net interest rate sensitivity considerably and brought an almost perfect match between assets and liabilities ${ }^{2}$. ATP also began using synthetic futures ${ }^{3}$ as a means to hedge its equity portfolio from the fall in global equity prices ${ }^{4}$. The reasons for using synthetic instead of traditional futures were that synthetic futures did not require a new operational setup and were the most cost efficient of the hedging instruments. The overall derivatives strategy was continued in 2003, and derivatives are now an integrated part of not only ATP's ALM framework but its active risk taking.

For ATP the use of derivatives turned out to be more than a hedging strategy. Its choice of interest rate swaps instead of, for example, a CMS floor option has been described as being on the aggressive side, as the interest rate swaps only work in ATP's favor as long as interest rates are falling and in that sense it was a hard bet on market direction. Fortunately, it was a good bet. Not only did ATP succeed in proactively matching the sensitivity of assets and liabilities and curbing risk exposure in volatile areas, but derivatives contributed considerably to the bottom line $e^{5}$ in 2002 and 2003 and as such proved a very profitable strategy.

\footnotetext{
${ }^{1}$ The contract amounted to DKK 65.1 billion with an estimated interest rate sensitivity of DKK 9.3 billion, which was only around half of the board approved limit for interest rate derivatives.

${ }^{2}$ At the end of 2002 ATP estimated that a 1 percent decrease in interest rates would cause provisions to increase by DKK 34.6 billion but return on assets would follow suit by an increase of DKK 31.7 billion.

${ }^{3}$ The synthetic futures were constructed from OTC options by selling call options and buying put options with the same strike price.

${ }^{4}$ This partial hedge reduced the equity exposure from 25 percent to 17.9 percent of investment assets, amounting to a risk reduction of DKK 17.6 billion.

${ }^{5}$ Interest rate swaps added DKK 12.6 billion to the annual result in 2002 and DKK 2.1 billion in 2003.
} 


\subsection{MAGISTRENES PENSIONSKASSE (MP): A PASSIVE STRATEGY}

MP is the tenth largest pension institution, excluding the statutory supplementary pension funds, such as ATP. More than 90 percent of its schemes have a guaranteed interest rate of 4.25 percent or higher, making its liabilities very interest rate sensitive.

Like other pension institutions with expensive interest rate guarantees on their books, MP was hit hard by falling global interest rates. The losses depleted its technical reserves ${ }^{1}$, leaving it dangerously close to insolvency.

Contrary to PFA and ATP, MP decided to ride out the storm. It used derivatives on a very limited scale and decided not to hedge interest rate risk, but rather to curb losses on its equity portfolio. MP's few active steps to alleviate the situation included:

- In 2002 it sold domestic bonds and bought euro bonds with longer duration to increase the interest rate sensitivity of its assets. However, this only increased duration marginally ${ }^{2}$ and assets and liabilities still remained significantly mismatched.

- Having seen its equity holdings reduced by close to 35 percent from 2001 to $2002^{3}$, it attempted to hedge against further losses by buying equity futures ${ }^{4}$. This was the only use of derivatives.

MP's reasoning for this passive strategy was that at the time it considered the cost of derivatives too high compared to the benefits. Though, in hindsight the passive strategy did not come cheap, either, and the fundamental problems arising from the asset/liability mismatch were not solved. Currently, MP is using derivatives (swaps and swapoptions) both as long-term strategic instruments to hedge interest rate risk and to gain market exposure through the use of currency forwards, and equity options.

\subsection{LESSONS FROM THE CASE STUDIES}

The most important lesson to be learned from the three cases is probably that prevention is better than cure. Without comparison, ATP has been the one to fare best through the stormy waters, and to a large extent this can be attributed to its proactive approach to asset/liability management. As suggested by the experiences of both PFA and MP, dealing with a crisis after it arises comes at a premium and narrows down considerably the choice of strategy.

Furthermore, the cases illustrate that derivatives are a very effective tool for bridging the gap between assets and liabilities. With the help of derivatives ATP has come close to a perfect match and PFA has managed to get its solvency situation under

\footnotetext{
${ }^{1}$ MP's technical reserves (base capital less solvency requirement / total liabilities) fell from 25.1 percent in late 2000 to 4.9 percent in late 2002, but improved to 8.7 percent in 2003.

${ }^{2}$ Duration on bonds was increased from 4.4 in 2001 to 7.0 years in 2002, but fell back to 5.1 in 2003.

${ }^{3}$ The equity portfolio decreased from DKK 12.6 billion in 2001 to DKK 8.2 billion in 2002 and slightly increased to DKK 8.3 billion in 2003.

${ }^{4}$ Equities were hedged by DKK 1.9 billion in 2002.
} 
control. In addition, both institutions have gained valuable knowledge on how to prevent future crises.

However, the experiences gained have been costly. Not only did the overwhelming demand for and scarce supply for long-duration assets push up the price on derivatives and, as in the case of MP, deter potential buyers, but the introduction of derivatives as hedging instruments brought along considerable internal costs stemming from necessary changes in internal procedures. Use of derivatives requires special administrative, legal, technical and human resources.

The fact that in the case of ATP the size of the derivatives contract was large enough to have an impact on the otherwise very liquid euro market underlines that the market is still small, compartmentalized and relatively illiquid. Therefore the perfect match might not be attainable through derivatives alone.

Neither are derivatives a quick or one-time only solution. Any hedging strategy needs to be carefully planned and closely monitored in order to be effective and even more so when dealing with fairly complicated instruments like derivatives. As the MP case shows, the impact of a temporary, partial hedge is exactly that, temporary and partial. Considering that pension sector liabilities are very sticky and that interest guarantees will continue to skew the balance sheet for many years to come, a long-term hedging strategy is needed.

\section{CONCLUSIONS}

Since their large scale industry-wide introduction in 2001, hedging instruments have been used successfully in Denmark to reduce interest rate and equity price risk. Derivatives, and the increased leverage they imply, have not increased overall exposure to market risks. On the contrary, derivatives have been used to significantly reduce the miss-match that existed between assets and liabilities. But they have increased exposure to operational and counterparty credit risk. As such they do not offer "a simple free lunch”.

The experience of Danish pension institutions in the early 2000s shows that it is imperative to adopt a comprehensive framework in risk management and measure the combined net sensitivity to interest rates and asset prices of assets, liabilities and derivatives on a regular basis. One could argue that pension institutions, finally, have begun to catch up to other types of financial institutions when it comes to regulatory as well as economic financial risk management. The move has revealed larger risks in the balance-sheet of the pension institutions than what was counted in the old framework. The changes have, therefore, reduced the risk-taking capabilities of the pension institutions (for a given level of capital). Unfortunately, this reduction comes at a time where the levels of required returns are increasing due to e.g. improvements in longevity risks over and above the levels expected in the actuarial calculations. Higher level of required returns would imply more risk taking, not less. Derivatives can be used to hedge liabilities in such a way that both capital and risk budget can be freed up and employed 
more gainfully in other (non-fixed income) asset classes, thereby increasing the return generating potential for any given amount of assets and capital.

The use of hedging instruments is also indispensable when pension institutions offer products with embedded options. The Danish pension institutions have been able to transform the pay-off curve of their balance sheets and to contain their risk exposures while avoiding a renegotiation of old contracts and without withdrawing completely the offer of products with embedded options.

Judicious use of derivatives would allow pension institutions to expand the offer of products with embedded options without assuming an intolerable exposure to interest rate and asset price risks. The solvency of pension institutions is determined by their combined asset, liability and derivative positions. However, the asset and liability composition provides an indication of the extent to which pension institutions offer products that meet the risk preferences of workers.

Products with embedded options avoid the transfer of all market risks to policyholders, who are likely to be the least suited to bear and handle these risks. The demand for such products is likely to increase over time as employer-sponsored defined benefit pension plans are increasingly closed to new members and are effectively replaced with defined-contribution plans. Under the latter, retirement benefits depend on the performance of financial markets. Transferring all the financial risk to workers may be inadvisable and may expose large numbers of individual workers to large financial losses and inadequate pension benefits.

However, successful use of hedging instruments would require sound derivative markets, sensible risk management practices, and effective regulatory oversight. All three would be critical elements for the sustainability of this approach. 


\section{BIBLIOGRAPHY}

Andersen, Carsten and Peter Skjodt. 2006. Pension Institutions and Annuities in Denmark. Mimeo. Washington D.C.: The World Bank.

Danish Financial Supervisory Authority. 2004. Report on the Determination of a Yield Curve for Discounting Insurance Liabilities. (Translated by the DIA). Copenhagen: DFSA and DIA.

Danish Pension Council. 2005. Pension Contributions, Replacement Ratios and Mortality. Copenhagen: DPC

Ministry of Economic and Business Affairs. 2003. Increased Freedom of Choice in Pension Saving. Copenhagen: MEBA.

Aase, K.K. and S.-A. Persson.1994. Pricing of unit-linked life insurance policies, Scandinavian Actuarial Journal, 26-52.

Baertelsen P. P., Kjeldsen K. 2003. Using derivatives to cover interest risk in pension companies (Danish). Danmarks Nationalbank (unpublished).

Bodie, Zvi and Robert C. Merton. 2002. "International Pension Swaps”, Journal of Pension Economics and Finance, vol. 1, issue 1.

Danish FSA. Pension Market Council’s annual reports (various) (in Danish)

Danish FSA. Market development for Life Insurance Companies, Pension Trusts and traditionally Insurance Companies (various years) (Danish).

Danish FSA. Report on Payment for Interest Rate Guarantees (Report in Danish, Review in English).

Danish FSA. 1999. Taxation of returns from pension savings, interest rate development and interest rate guarantees (Danish) - Report from the Pension Market Council

Danmarks Nationalbank - Financial stability (various years) http://nationalbanken.dk

Danmarks Nationalbank. 2006. Speech by Governor Nils Bernstein: The role of the pension sector in the economy.

Danske Bank. 2002. Provisions in the L\&P Industry using the new Mark to Market rules Investment strategy 2002/2003.

Dydensborg L. 2001. SWAP products - applications in insurance and pension companies (Danish) - Danske Bank, Danish research

Gosvig M., Wind L. 2004. ATP - The pension industry’s view on derivatives (Danish) Finans/Invest 08/04

Grosen A. 1998. The interest rate guarantee - a bomb under the pension system! (Danish). Finans/Invest 3/98

Grosen A., Jorgensen P. L. 2002. Focus at the Risk of Pension Saver' Rate of Return on investment (Danish). Finans/Invest 232, 6/02

Grosen A., Jorgensen P. L. 1999. Valuation of Pension Liabilities - An Option Based Approach (Danish) - Finans/Invest 7/99 
Guillen M., Jorgensen P. L., Perch-Nielsen J. 2006. Return Smoothing Mechanisms in Life and Pension Insurance - Path-dependent Contingent Claims. Working Paper, University of Aarhus.

Jamshidian, F. 1997. "Libor and swap market models and measures," Finance and Stochastics, 1:293330.

Jorgensen P. L. 2004. On Accounting Standards and Fair Valuation of Life Insurance and Pension Liabilities - University of Aarhus, Department of Management.

Jorgensen P. L., Grosen A. 2002. Life insurance Liabilities at Market Values: An Analysis of Insolvency Risk, Bonus Policy, and Regulatory Intervention Rules in a Barrier Option Framework - Journal of Risk and Insurance, Vol. 69, No. 1 (2002), pp. 63-91

Jorgensen P. L., Grosen A. 2002. The Bonus-crediting mechanism of Danish Pension and Insurance Companies: an empirical analysis - PEF, 1 (3): pp. 249-268, November 2002, Cambridge University Press

Jorgensen P. L., Grosen A. 1997. Valuation of early exercisable interest rate guarantees The Journal of Risk and Insurance, Vol. 64, No. 3, pp. 481-503

Ladekarl, J. 1998. "Safeguarding investment in Danish mortgage bonds", Journal of Financial Regulation and Compliance.

Ministry of Social Affairs Denmark - National strategy report on Danish pension system (various years)

Mogensen L. 2002. Market Dynamics at Low Interest Rates, Monetary Review, Danmarks Nationalbank

Nielsen J. P., Jorgensen P. L. 2002. Time Pension (Danish) - Finans/Invest 232, 6/02

Nykredit Markets. 2003. Investor Focus.

Rasmussen M. L. 2001. Hedging of Interest Risk in Life and Pension Companies (Danish) KPMG Financial Services, Newsletter.

Sørensen, C. 1999. "Dynamic asset allocation and fixed income management," Journal of Financial and Quantitative Analysis, 34(4):513531.

Van Dam, Rein and Erik Brink Andersen. 2006. Risk-Based Supervision of Pension Institutions in Denmark. Mimeo. Washington D.C. The World Bank. 